\title{
Effect of pre-sowing Application of Nitrogen, Potassium and Sulfur and its relationship on Egyptian Cotton Productivity.
}

\author{
Amany A.El-Ashmouny ${ }^{1}$, Kholoud A.El-Naqma ${ }^{2}$, Azza A. El-Hendawy ${ }^{3}$ \\ ${ }^{1,3}$ Cotton Research Institute,A.R.C, Giza, Egypt \\ ${ }^{2}$ Soils, Water and Environment, Res. Ins. A.R.C, Giza, Egypt
}

\begin{abstract}
Fertilizer use in till systems must be aligned with a correct interpretation of soil chemical attributes and cotton demands. The objectives of this work were evaluate the effect of pre-sowing application of urea, potassium and sulfate on the yield of cotton and soil chemical attributes of till cotton (Gossypium barbadense L.) over two harvesting years. The experiment was arranged in complete randomized block design; the doses of an activation macronutrients were the quarter of recommended dose of them. We were applied the recommended doses of $N, P, K$ on soil. The cotton plants in the experimental plots were manually harvested on October 25, 2015 and October 15, 2016. The soil samples were collected between cotton rows in all plots before sowing on March 27, 2015 and April 1, 2016 at depth of $(0-30,30-60$ and $60-90 \mathrm{~cm})$ for soil fertility analyses.

-The increasing doses of $N, K, S$ induced a higher values when we addition mixture of urea, potassium and sulfate on plant height, no. of fruiting branches, no. of open bolls before harvest, boll weight, seed cotton yield/ kentar, lint \% , micronaire values and pressely values.

-On the other hand, \% earliness increased by control and reduced by addition the mixture of nutrients.

-The mixture $(N+k+S)$ treatment had the highest values of available $N$ and $S$ in the first and second respectively compared with the control treatment.

-The addition of potassium Sulphate had gaven a highest values of available $K$ in the first and second seasons respectively compared with the control treatment.

-The Mixture treatment had gaven a highest values of $N: K$ which reflected on a Lint\% and seed cotton yield/fed at the first and second season, respectively

-The control treatment had highest values of $N$ : $S$ ration which affected on seed cotton. It gave a lowest values of seed cotton yield/fed. But the treatment of mixture $(N+K+$ $S)$ gave moderate values of $N: S$ ratio while it was gave a
\end{abstract}

highest values of seed cotton yield / fed.

-The highest values of $N$ concentration in fourth leaf (last mature leaf) due to treatment with $N$ (urea) in the first and second seasons. But it had gaven a lowest yield compared with the control treatments.

-The highest values of $K$ concentration led to $K$ (potassium sulfate) treatment compared with the control in first and second seasons, respectively

-The highest values of $N$ : $K$ ratio was obtained with $N$ ( urea ) treatment. It led to decrease in the seed cotton yield/ fed but the highest values of yield / fed was obtained when added all mineral fertilizers as a mixture in soil when $N: K$ was as a compared on control treatments.

- The second treatment which caused a highest in yield after mixture treatment was $k$ (potassium sulphate), it had gaven ( $9.01 \& 9.64$ ) yield/fed while $N: K$ was $(0.34 \& 0.32$ ) in the first and second seasons respectively.

Keywords-Gossypium barbadense, fertilizer management, Macronutrients, pre-sowing.

\section{INTRODUCTION}

Cotton is an important crop worldwide, with a high aggregated value due to its many processed derivates and the high consumer demand. Fertilizer recommendation forcotton is based on soil and leaf analysis. However, it is necessary to interpret such results with respect to the field management history. Soil fertility evaluation aims to quantify the availability of soil nutrients in order to overcome deficiencies and promote the growth and development of plants (CANTARUTTI et al, 2007). Nitrogen is the nutrient most necessary to the cotton plant, an excess or deficiency can lead to losses in cotton yield and quality (Rosolen and Van Mellis, 2010).The occurrence of $\mathrm{K}$ in stomata activity when the sun energy is used to combine co2and water to form sugars, the initial high- energy product is ATP. The ATP is then used as an 
energy source for many other chemical reactions; potassium also plays a major role in the transport of water and nutrients throughout the plant in the xylen. When K supply is reduced trans location of nitrates phosphates, Calcium magnesium and Amino acids is depressed. The role of Sulfur deficiency in cotton has increased due to the decrease in the use of S-bearing fertilizer and reduced atmospheric $\mathrm{S}$ deposion.the application of it increased the lint $\%$ by $8: 9 \%$ and micronaire by $4: 5 \%$ when compared to control over growing seasons.

Therefore, this work aims to evaluate the effects of presowing application of Urea, Potassium, Sulfate and their mixture on cotton yields and soil chemical attributes over two years.

\section{MATERIALS AND METHODS}

An experiment was performed at Sakha Agriculture

Research station, Kafr El- Sheikh, Egypt to study the effect of addition some macronutrients before sowing cotton plants ( Giza 94 cultivar).

This investigation included one experiment was carried out during 2015 and 2016 seasons as follows:-

1- Control (recommended dose) of $\mathrm{P}$ before sowing and splitting $\mathrm{N}$ during the growth period.

2- Addition Urea before sowing (46.5\% N) $15 \mathrm{~kg}$ N.fed ${ }^{-1}$.

3- Addition potassium Sulphate (48\% K2O) $6 \mathrm{~kg}$ $\mathrm{k}_{2} \mathrm{O}$.fed $\mathrm{f}^{-1}$

4- Addition Micronic Sulfur (80\% S) 2 kg.fed ${ }^{-1}$

5- Addition the mixture of $(\mathrm{N}+\mathrm{K}+\mathrm{S})$.

Preceding crop was Egyptian clover in the two seasons.

Chemical analyses for the experimental field were done at Sakha agricultural Research Station. Soil samples air dried crushed, some physical and chemical properties were determined according to Jackson, (1967) and Black et al. (1965) some soil chemical and physical properties (Table $1)$.

Table.1:- Chemical properties of the top experimental soil at 2015 and 2016 seasons.

\begin{tabular}{|c|c|c|c|c|c|c|c|c|c|c|c|c|c|c|c|c|c|}
\hline \multirow{2}{*}{$\begin{array}{l}\text { Seas } \\
\text { o-ns }\end{array}$} & \multicolumn{3}{|c|}{$\begin{array}{c}\text { Partical size } \\
\text { distribert }\end{array}$} & \multirow{2}{*}{$\begin{array}{l}\text { Te } \\
\text { xt- } \\
\text { ure }\end{array}$} & \multirow{2}{*}{$\mathrm{pH}$} & \multirow{2}{*}{$\begin{array}{c}\mathrm{E} \\
\mathrm{C} \\
\mathrm{ds} \\
/ \\
\mathrm{m}\end{array}$} & \multicolumn{4}{|c|}{ Cation meq/L } & \multicolumn{4}{|c|}{ Anion meq/ l } & \multirow{2}{*}{$\begin{array}{c}\mathrm{N} \\
\mathrm{ppm}\end{array}$} & \multirow{2}{*}{$\begin{array}{c}\mathrm{P} \\
\mathrm{ppm}\end{array}$} & \multirow{2}{*}{$\begin{array}{c}\mathrm{K} \\
\mathrm{ppm}\end{array}$} \\
\hline & $\begin{array}{l}\text { Sa } \\
\text { nd }\end{array}$ & silt & $\begin{array}{c}\text { cla } \\
\mathbf{y}\end{array}$ & & & & $\begin{array}{l}\mathrm{Ca} \\
++ \\
+\end{array}$ & $\begin{array}{c}\mathrm{Mg}^{+} \\
+ \\
\end{array}$ & $\begin{array}{l}\mathrm{Na} \\
+ \\
\end{array}$ & $\mathrm{K}^{+}$ & $\begin{array}{c}\text { Co } \\
3 \\
\end{array}$ & $\begin{array}{l}\mathrm{Hc} \\
\mathrm{O}_{3} \\
\end{array}$ & $\mathrm{Cl}$ & $\begin{array}{c}\mathrm{SO} 4 \\
- \\
\end{array}$ & & & \\
\hline $1^{\text {st }}$ & 11 & $\begin{array}{c}38 . \\
3\end{array}$ & $\begin{array}{c}50 . \\
7\end{array}$ & $\begin{array}{l}\text { cla } \\
\text { yey }\end{array}$ & $\begin{array}{c}8.1 \\
5\end{array}$ & $\begin{array}{l}2 . \\
6\end{array}$ & 7.8 & 6.6 & $\begin{array}{l}8 . \\
1\end{array}$ & 3.5 & - & 3 & 17 & 6 & 35.39 & 7.7 & 235.1 \\
\hline $2^{\text {nd }}$ & $\begin{array}{c}11 . \\
2\end{array}$ & $\begin{array}{c}38 . \\
1\end{array}$ & $\begin{array}{c}50 . \\
7\end{array}$ & $\begin{array}{l}\text { cla } \\
\text { yey }\end{array}$ & $\begin{array}{c}8.1 \\
5\end{array}$ & $\begin{array}{l}2 . \\
7\end{array}$ & 8 & 6.6 & $\begin{array}{l}8 . \\
3\end{array}$ & 3.7 & - & 3.1 & 18 & 5.9 & 33.14 & 7.23 & 220.0 \\
\hline
\end{tabular}

Experiment plot consisted of five rows , $4 \mathrm{~m}$ along and 0.7 $\mathrm{m}$ width (plot area $=14 \mathrm{~m} 2$ ). The seeds were sown on 10 and 12 April in first and second seasons, respectively. The treatment of macronutrients was applied before sowing the plants and after tillage system between rows with nitrogen at a rate of ( $15 \mathrm{KG} / \mathrm{fed})$ in the form of Urea (46.5\%) for treatment 2 , potassium sulphate at a rate of $(6 \mathrm{Kg} \mathrm{K} 2 \mathrm{O} /$ fed) in the form of potassium sulphate for treatment 3 , finally, sulfur at a rate of $(2 \mathrm{~kg} \mathrm{~S} / \mathrm{fed})$ in the form of Micronic sulfer for treatment 4 . They all as an activation dose adding before sowing.

All plots were soil fertilized with nitrogen fertilizer at a rate of $(60 \mathrm{~kg} \mathrm{~N})$ in two equal doses, the first dose was applied after thinning, while the second one was applied before the second irrigation but the second treatment $(\mathrm{N})$ only fertilized with nitrogen fertilizer at a rate of $(15 \mathrm{~kg} \mathrm{~N} / \mathrm{fed})$ in three equal dose, the first dose was applied before sowing at a rate of ( $15 \mathrm{KG} / \mathrm{fed})$ in the form of Urea $(46.5 \%)$, while the second dose was applied after thinning at a rate of $(22.5 \mathrm{~kg}$ $\mathrm{N}$ ), at the last , the third dose was applied before the second irrigation at a rate of $(22.5 \mathrm{~kg} \mathrm{~N})$ as a complete dose. Phosphorus fertilizer was applied during soil preparation in the form of Calcium Super Phosphate (15.5 P2o5) at a rate of $100 \mathrm{KG} / \mathrm{fed}$, potassium fertilizer was applied before the beginning of flowering stage in the form potassine $\mathrm{F}$.

\section{Character studied:-}

\section{A) Growth characters:-}

Samples of five guarded plants were taken at random from experimental plot at 120 days after sowing to estimate the following groth characters:-

1- Plant height $(\mathrm{cm})$

2- No. of fruiting branches

B) Yield and its components:-

At first pick, random sample of ten guarded plants was 
taken and labeled from each plot to determine the following characters:-

1- No. of open polls / plant.

2- Boll weight (g)

3- Seed index (100-seed weight)

4- Earliness $\%=$ seed cotton yield of the first pick / total seed cotton yield x 100

5- Lint \%= weight of lint / plant / weight of seed cotton / plant x 100

6- Seed cotton yield / fed ( Kentar, i.e $157.5 \mathrm{~kg}$ )

\section{c) Fiber characters:-}

Samples of lint were collected from each treatment at each replicate to determine the following characters:-

1- Fiber fineness ( micronaire): it was determined by HVI.

2- Fiber streingth (pressely index) it was determined by HVI.

D) chimecal analysis :-

Available nitrogen of the soil was extracted by $1 \mathrm{~N}$ potassium chloride and determined by Kjleldhl method (Jackson, 1967), phosphorus was extracted by $0.5 \mathrm{~N}$ Sodium bicarbonate and colormitrically measured by spectrophotometer (Jackson, 1967). Plant samples ( the fourth leaf as the first mature leaf ) oven dried 700C and ground thoroughly, wet digested using sulphoric and perchloric acids mixture, total nitrogen and total phosphorus were determined according to Jackson (1967) N utilization rate was calculated according to the equation $\mathrm{N}$ utili. $=\mathrm{N}$ uptake for treatment $-\mathrm{N}$ uptake for control / $\mathrm{N}$ upplied for treatment.
E) Statical analysis:-

The analysis of varience for complete randomized block design was carried out for each character in each season as out lined by Snedecor and Cochran(1967). The differences between the means of different treatment were tested using (LSD) at 5\% level of probability were used to compare between treatments means.

\section{RESULTS AND DISCUSSION}

It is very important to know that, the nutrients elements play the main role in plant life either vegetative growth, flowering stages as well as yield stages. Moreover, the macronutrients make an important role in increasing the productivity of cotton crop through activation of many structural, catalytically, electronical and vital processing in plant. Therefore, the results will be classified as follows:-

\section{A) Growth characters:-}

The effect of activation dose of some macronutrients on some vegetative growth and development parameters were studied at 120 days after sowing.

\section{1- Plant height}

Data recorded in table (2) showed that, plant height was significantly increased by the application of all tested macronutrients eigher separately or mixes as compared with untreated plants in 2015 season. Moreover, 2016 seson was not significant.

\section{2- Number of fruiting branches / plant.}

With regard to the number of fruiting branches / plant. The results in table (2) show that addition mixture of three macronutrients produced the highest number of fruiting branches / plant compared to other tested macroelements in two growing seasons.

Table.2: Effect of addition some macronutrients as an activation dose on plant height and no. of fruiting branches/ plant during 2015 and 2016 seasons.

\begin{tabular}{|c|c|c|}
\hline No.of fruiting branches & Plant height & Characters Treatments \\
\hline \multicolumn{3}{|l|}{2015 season } \\
\hline $18.30 \mathrm{c}$ & $161.83 \mathrm{~b}$ & Control \\
\hline $18.80 \mathrm{bc}$ & $162.80 \mathrm{~b}$ & $\mathrm{~N}$ \\
\hline $19.20 \mathrm{ab}$ & $163.21 \mathrm{~b}$ & K \\
\hline $18.67 \mathrm{c}$ & $162.26 \mathrm{~b}$ & $S$ \\
\hline $19.47 \mathrm{a}$ & $167.36 \mathrm{a}$ & Mix. \\
\hline \multicolumn{3}{|l|}{2016 season } \\
\hline $18.33 \mathrm{~d}$ & 181.66 & Control \\
\hline $19.66 \mathrm{bc}$ & 186.66 & $\mathrm{~N}$ \\
\hline $20.33 \mathrm{ab}$ & 173.33 & $\mathrm{~K}$ \\
\hline $19.00 \mathrm{~cd}$ & 193.33 & $\mathrm{~S}$ \\
\hline $21.33 \mathrm{a}$ & 195.00 & Mix \\
\hline
\end{tabular}




\section{B) Yield and its components:-}

It is clear from data recorded in table (3) that, addition of some macronutrients had significant effect on cotton yield and its components.

\section{1- No. of open bolls / plant.}

It is clear from the data presented in the same table that, the application of nutrients significantly increased number of open bolls / plant compared with control plants in both seasons. The maximum values were (28.92 and 33.36) obtained from adding mixture of $(\mathrm{N}, \mathrm{K}$ and $\mathrm{S})$. In this respect, many investigators found that, no. of open bolls / plant was increased by addition the mixture of macronutrient.

\section{2- Boll weight (g)}

From the data in the table we found that, application addition of some macronutrients and their mixture tended to increase boll weight/ plant significantly in the first season. Moreover, mixture addition increased boll weight compared with other treatments.

\section{3- Seed index (100-seed weight)}

Results in the same table show not significant differences among addition some macronutrients for 100-seed weight in both seasons.

\section{4- Earliness \%}

The values of earliness $\%$ were increased by addition sulfer nutrients and untreated plants. On the other hand, it can be noticed that the application of $\mathrm{N}$ and mixture gave the lowest values of earliness \% in the first season.morover; the second season was not significant.

\section{5- Lint \%}

Results in the table clear that, lint percentage was increased by addition $\mathrm{K}, \mathrm{S}$ and mixture before sowing cotton plants compared to addition of $\mathrm{N}$ and untreated plants in the second season.

\section{6- Seed cotton yield / faddan (Kentar)}

Seed cotton yield was significantly increased with the tested microelements and their mixture compared to control in both seasons. Moreover, it can be noticed that, addition of mixture produced the highest values, i.e. 26.13 and $14.54 \%$ more than control treatment in the first and second seasons, respectively. The highest increase in seed cotton yield / fed by addition mixture of ( $N, K$ and $S$ ) might be directly attributed to increase in yield components (no.of open bolls and boll weight).In this concern, Twolde et al (2005) found that mixture of some macronutrients increased seed cotton yield over control treatment about $12.5 \%$.

Table.3: Effect of addition some macro elements and their mixture on yield and its components of cotton during 2015 and 2016

\begin{tabular}{|c|c|c|c|c|c|c|}
\hline $\begin{array}{l}\text { Seed cotton } \\
\text { yield / fed }\end{array}$ & Lint $\%$ & Earliness \% & Seed index & $\begin{array}{c}\text { Boll weight } \\
\text { (g) }\end{array}$ & $\begin{array}{c}\text { No.of open } \\
\text { bolls }\end{array}$ & \\
\hline \multicolumn{6}{|c|}{2015} & \\
\hline $7.73 \mathrm{~d}$ & 41.00 & $68.05 \mathrm{a}$ & 12.37 & $3.06 \mathrm{~b}$ & $24.89 \mathrm{c}$ & Control \\
\hline $8.23 \mathrm{bc}$ & 40.30 & $62.78 \mathrm{~b}$ & 12.29 & $3.24 \mathrm{a}$ & $25.67 \mathrm{c}$ & $\mathrm{N}$ \\
\hline $9.01 \mathrm{ab}$ & 40.90 & $63.57 \mathrm{~b}$ & 12.17 & $3.25 \mathrm{a}$ & $27.30 \mathrm{~b}$ & $\mathrm{~K}$ \\
\hline $8.00 \mathrm{c}$ & 42.12 & $66.06 \mathrm{a}$ & 12.31 & $3.08 \mathrm{~b}$ & $24.93 \mathrm{c}$ & $\mathrm{S}$ \\
\hline $9.75 \mathrm{a}$ & 42.09 & $62.11 b$ & 12.00 & $3.31 \mathrm{a}$ & $28.92 \mathrm{a}$ & Mixture \\
\hline \multicolumn{6}{|c|}{2016} & \\
\hline $8.73 \mathrm{~d}$ & $41.76 \mathrm{c}$ & 69.72 & 12.53 & 2.93 & $28.83 \mathrm{~d}$ & Control \\
\hline $9.50 \mathrm{bc}$ & $42.56 \mathrm{~b}$ & 61.14 & 12.33 & 3.03 & $33.63 \mathrm{a}$ & $\mathrm{N}$ \\
\hline $9.64 \mathrm{~b}$ & $43.26 \mathrm{a}$ & 66.39 & 12.30 & 3.11 & $31.33 \mathrm{~b}$ & $\mathrm{~K}$ \\
\hline $9.00 \mathrm{~cd}$ & $43.13 \mathrm{ab}$ & 67.77 & 12.47 & 2.96 & $29.59 \mathrm{~cd}$ & $\mathrm{~S}$ \\
\hline 10.0 & $43.37 \mathrm{a}$ & 64.51 & 12.16 & 3.12 & $33.63 \mathrm{a}$ & Mixture \\
\hline
\end{tabular}

\section{C) Technological characters of fibers.}

It is clear from table (4) that the application addition of some macronutrients led to significant increase in all studied technological characters of fibers (fiber length and fiber fineness) as compared with that obtained from the control plants in both seasons. 
Table.4: Effect of mixture of macronutrients on technological characters

\begin{tabular}{|c|c|c|c|c|}
\hline Fiber fineness & Fiber strength & Fiber fineness & Fiber strength & \\
\hline \multicolumn{2}{|c|}{2016} & \multicolumn{2}{|c|}{2015} & Control \\
\hline $4.2 \mathrm{~b}$ & $10.2 \mathrm{a}$ & $4.1 \mathrm{~b}$ & $9.8 \mathrm{ab}$ & $\mathrm{N}$ \\
\hline $4.5 \mathrm{a}$ & $9.8 \mathrm{~b}$ & $4.5 \mathrm{a}$ & $9.6 \mathrm{~b}$ & $\mathrm{~K}$ \\
\hline $4.5 \mathrm{a}$ & $10.1 \mathrm{a}$ & $4.5 \mathrm{a}$ & $9.9 \mathrm{a}$ & $\mathrm{S}$ \\
\hline $4.4 \mathrm{a}$ & $9.4 \mathrm{c}$ & $4.3 \mathrm{ab}$ & $9.3 \mathrm{c}$ & Mixture \\
\hline $4.4 \mathrm{a}$ & $10.3 \mathrm{a}$ & $4.5 \mathrm{a}$ & $10.0 \mathrm{a}$ & \\
\hline
\end{tabular}

The highest values of these characters were mostly obtained by potassium and mixture of macronutrients for fiber strength and fineness in the first and second seasons. In this respect, Twolde et al. (2005) found that fiber strength and fiber fineness were significantly increased by foliar application with some macro elements.

\section{D) Chemical caracters:-}

Table.5: Effect of some $N, K, S$ and their mixture fertilization on Available $N, K$ and $S \mathrm{mg}^{-\mathrm{kg}^{-1}}$ at the soil after harvest .

\begin{tabular}{|l|c|c|c|c|c|c|}
\hline \multirow{2}{*}{ control } & \multicolumn{2}{|c|}{ Available N } & \multicolumn{2}{c|}{ Available K } & \multicolumn{2}{c|}{ Available S } \\
\cline { 2 - 7 } & $\mathbf{1}^{\text {st }}$ & $\mathbf{2}^{\text {nd }}$ & $\mathbf{1}^{\text {st }}$ & $\mathbf{2}^{\text {nd }}$ & $\mathbf{1}^{\text {st }}$ & $\mathbf{2}^{\text {nd }}$ \\
\hline $\mathbf{N}$ & $32.00 \mathrm{e}$ & $31.7 \mathrm{e}$ & $206.00 \mathrm{e}$ & $201.3 \mathrm{e}$ & $3.23 \mathrm{e}$ & $2.92 \mathrm{e}$ \\
\hline K & $55.00 \mathrm{~b}$ & $51.7 \mathrm{~b}$ & $333.70 \mathrm{c}$ & $327.70 \mathrm{c}$ & $9.97 \mathrm{~d}$ & $8.30 \mathrm{~d}$ \\
\hline S & $45.00 \mathrm{~d}$ & $43.7 \mathrm{~d}$ & $405.70 \mathrm{a}$ & $402.0 \mathrm{a}$ & $59.00 \mathrm{c}$ & $54.67 \mathrm{c}$ \\
\hline Mixture & $50.70 \mathrm{c}$ & $48.7 \mathrm{c}$ & $322.30 \mathrm{~d}$ & $313.7 \mathrm{~d}$ & $78.33 \mathrm{~b}$ & $73.33 \mathrm{~b}$ \\
\hline \multicolumn{1}{r|}{ LSD } & $60.30 \mathrm{a}$ & $58.7 \mathrm{a}$ & $342.70 \mathrm{~b}$ & $339.0 \mathrm{~b}$ & $83.33 \mathrm{a}$ & $78.33 \mathrm{a}$ \\
\hline
\end{tabular}

The data obtained from Table (5) show that a significant effect of all treatments on available $\mathrm{N}, \mathrm{K} \& \mathrm{~S}$ after harvest . The mixture $(\mathrm{N}+\mathrm{k}+\mathrm{S})$ treatment had the highest values of available $\mathrm{N}$ and $\mathrm{S}$ ( $60.3 \& 58.7$ ) and ( $83.33 \& 78.33$ ) in the first and second Respectively compared with the control treatment. On the other hand the addition of potassium Sulphate had gaven a highest values of available K ( 405.7\& 402.0 ) in the first and second seasons respectively compared with the control treatment. These results may be due to potassium sulphate and sulphur still in the soil because they less mobile in the soil. These results are agree with those obtained by Tisdale et. al.(1990) who found that, the $\mathrm{K}^{+}$ion is held around negatively charged soil colloids by electrostatic attraction. Cations held in this manner are easily displaced or exchanged when the soil is brought into contact with neutral salt solutions. The amount of potassium exchanged varies with the cation used in the measurement.

Also, They found that the inorganic forms are readilysoluble sulfate, adsorbed sulfate, insoluble sulfate coprecipitated with calcium carbonate, and reduce inorganic sulfur compounds. Scince plants obtained sulfur primarily from soil as dissolved sulfate, easily soluble sulfate plus adsorbed sulfate represent the readily available fraction of soil sulfur which is utilized by plants.

Table.6: The relationship between $N: K, N: S$ ration at the soil after harvest and their association on lint\% and seed cotton yield / fed.

\begin{tabular}{|c|c|c|c|c|c|c|c|c|}
\hline \multirow{2}{*}{} & \multicolumn{2}{|c|}{$\mathbf{N}$} & \multicolumn{2}{c|}{ N:S } & \multicolumn{3}{c|}{ Lint\% } & \multicolumn{2}{c|}{$\begin{array}{c}\text { Seed cotton yield / } \\
\text { fed }\end{array}$} \\
\cline { 2 - 9 } & $\mathbf{1}^{\text {st }}$ & $\mathbf{2}^{\text {nd }}$ & $\mathbf{1}^{\text {st }}$ & $\mathbf{2}^{\text {nd }}$ & $\mathbf{1}^{\text {st }}$ & $\mathbf{2}^{\text {nd }}$ & $\mathbf{1}^{\text {st }}$ & $\mathbf{2}^{\text {nd }}$ \\
\hline Control & $0.155 \mathrm{c}$ & 0.157 & $9.92 \mathrm{a}$ & $10.86 \mathrm{a}$ & 41.00 & $41.76 \mathrm{c}$ & $7.73 \mathrm{~d}$ & $8.73 \mathrm{~d}$ \\
\hline N (urea) & $0.165 \mathrm{~b}$ & 0.158 & $5.52 \mathrm{~b}$ & $6.23 \mathrm{~b}$ & 40.30 & $42.56 \mathrm{~b}$ & $8.23 \mathrm{bc}$ & $9.50 \mathrm{bc}$ \\
\hline K (potassium sulphat) & $0.111 \mathrm{~d}$ & 0.109 & $0.76 \mathrm{c}$ & $0.6 .23 \mathrm{c}$ & 40.90 & $43.26 \mathrm{a}$ & $9.01 \mathrm{ab}$ & $9.64 \mathrm{~b}$ \\
\hline S (gypsum) & $0.157 \mathrm{c}$ & 0.155 & $0.65 \mathrm{c}$ & $0.664 \mathrm{c}$ & 42.09 & $43.13 \mathrm{ab}$ & $8.00 \mathrm{c}$ & $9.00 \mathrm{~cd}$ \\
\hline Mixture(N+k+S) & $0.176 \mathrm{a}$ & 0.173 & $0.724 \mathrm{c}$ & $0.750 \mathrm{c}$ & 42.12 & $43.37 \mathrm{a}$ & $9.75 \mathrm{a}$ & $10.00 \mathrm{a}$ \\
\hline LSD & $\mathbf{2 . 0 1}$ & $\mathbf{0 . 0 0 5}$ & $\mathbf{0 . 5 7}$ & $\mathbf{0 . 7 6}$ & & & & \\
\hline
\end{tabular}


The data obtained from Table (6) show that a significant effect of all treatments on relations between $\mathrm{N}: \mathrm{K}, \mathrm{N}: \mathrm{S}$, Lint $\%$ and seed cotton yield/fed .Data observed that the Mixture treatment had gaven a highest values of $\mathrm{N}: \mathrm{K}$ which reflected on a Lint\% and seed cotton yield/fed . they were ( $42.12 \& 43.37$ ) for lint $\%$ and ( $9.75 \& 10.00$ ) for seed cotton yield/fed at the first and second season, respectively . On the other hand the control treatment had a highest values of $\mathrm{N}: \mathrm{S}$ ration which affected on seed cotton. It gave a lowest values of seed cotton yield/fed. But the treatment of mixture $(\mathrm{N}+\mathrm{K}+\mathrm{S})$ gave moderate values of
$\mathrm{N}: \mathrm{S}$ ratio while it was gave a highest values of seed cotton yield / fed. .

This may be due to the plants absorbed the elements in equilibrium amount and deficiency in one element limits the growth and yield. These results are agree with those obtained by Mengel, et al. 1987. Who show that in the soil, the concentration of $\mathrm{N}$ dissolved in the soil solution can change considerably over short period ( leaced into deeper soil layers, Nitrification, taken up by plant root so the NO3content of the soil solution is of major importance in plant nitrogen nutration.

Table.7: Relationship between applied $N, K, S$, their mixture on the ratio between $N$ and $K$ in the plant and its effect on seed cotton yield.

\begin{tabular}{|c|c|c|c|c|c|c|c|c|}
\hline \multirow{2}{*}{} & \multicolumn{2}{|c|}{$\mathbf{N \%}$} & \multicolumn{2}{c|}{ K\% } & \multicolumn{2}{c|}{ N:K } & \multicolumn{2}{c|}{ Seed cotton yield / fed } \\
\cline { 2 - 9 } & $\mathbf{1}^{\text {st }}$ & $\mathbf{2}^{\text {nd }}$ & $\mathbf{1}^{\text {st }}$ & $\mathbf{2}^{\text {nd }}$ & $\mathbf{1}^{\text {st }}$ & $\mathbf{2}^{\text {nd }}$ & $\mathbf{1}^{\text {st }}$ & $\mathbf{2}^{\text {nd }}$ \\
\hline control & $0.90 \mathrm{~d}$ & $0.783 \mathrm{~d}$ & $1.18 \mathrm{e}$ & $1.02 \mathrm{~d}$ & $0.76 \mathrm{~b}$ & $0.767 \mathrm{~b}$ & $7.73 \mathrm{~d}$ & $8.73 \mathrm{~d}$ \\
\hline $\mathbf{N}$ (urea) & $2.13 \mathrm{a}$ & $1.900 \mathrm{a}$ & $1.63 \mathrm{~d}$ & $1.33 \mathrm{~d}$ & $1.30 \mathrm{a}$ & $1.447 \mathrm{a}$ & $8.23 \mathrm{bc}$ & $9.50 \mathrm{bc}$ \\
\hline $\begin{array}{c}\text { K (potassium } \\
\text { sulphat) }\end{array}$ & $1.38 \mathrm{bc}$ & $1.183 \mathrm{~b}$ & $4.03 \mathrm{a}$ & $3.70 \mathrm{a}$ & $0.34 \mathrm{c}$ & $0.32 \mathrm{c}$ & $9.01 \mathrm{ab}$ & $9.64 \mathrm{~b}$ \\
\hline S (gypsum) & $1.26 \mathrm{c}$ & $0.990 \mathrm{c}$ & $2.80 \mathrm{c}$ & $2.467 \mathrm{c}$ & $0.45 \mathrm{bc}$ & $0.403 \mathrm{c}$ & $8.00 \mathrm{c}$ & $9.00 \mathrm{~cd}$ \\
\hline Mixture(N+k+S) & $1.55 \mathrm{~b}$ & $1.217 \mathrm{~b}$ & $3.53 \mathrm{~b}$ & $3.10 \mathrm{~b}$ & $0.44 \mathrm{bc}$ & $0.393 \mathrm{c}$ & $9.75 \mathrm{a}$ & $10.00 \mathrm{a}$ \\
\hline LSD & $\mathbf{0 . 2 1}$ & $\mathbf{0 . 1 3 3}$ & $\mathbf{0 . 3 3}$ & $\mathbf{0 . 3 5}$ & $\mathbf{0 . 1 6}$ & $\mathbf{0 . 1 7 8}$ & & \\
\hline
\end{tabular}

Data in Table (7) show that a significantly increased in $\mathrm{N}$ : K ration due to $\mathrm{N}$ fertilization. Data demonstrated that the highest values of $\mathrm{N}$ concentration in fourth leaf (last mature leaf) due to treatment with $\mathrm{N}$ (urea) $(2.13 \& 1.90 \%)$ in the first and second seasons . But it had given a lowest yield compared with the control treatments. These results agree with Gormus et al., 2016; who found that $\mathrm{N}$ deficiency decrease fiber length, lint \% yield without any fertilizer with it . On the other hand, the highest values of $\mathrm{K}$ concentration led to $\mathrm{K}$ (potassium sulfate) treatment compared with the control in first and second seasons, respectively. It was (4.03 and 3.70\%) respectively. These results due to potassium presence in the clay minerals and there are equilibrium between the three status (soluble, exchangeable and fixed ) while $\mathrm{N}$ lost quickly from the soil. A gree with

( Ehsan Akhtar, et al., 2003; Xiaoli Tian et al., 2016 ) which they show that seed cotton yield increased with $\mathrm{K}$ fertilizers .

Also data show that a relation between $\mathrm{N}$ : $\mathrm{K}$ ratio and yield of cotton. The highest values of $\mathrm{N}$ : $\mathrm{K}$ ratio was obtained with $\mathrm{N}$ ( urea ) treatment which was ( $1.30 \& 1.447)$. It led to decrease in the seed cotton ( $8.23 \& 9.5$ ) yield / fed but the highest values of yield ( $9.75 \& 10.00$ ) yield / fed was obtained when added all mineral fertilizers as a mixture in soil when $\mathrm{N}: \mathrm{K}$ was ( $0.44 \& 0.393$ ) as a compared on control treatments . the second treatment which caused a highest in yield was $\mathrm{k}$ ( potassium sulphate ), it had gaven ( $9.01 \& 9.64)$ yield/fed while $\mathrm{N}: \mathrm{K}$ was $(0.34 \& 0.32)$ in the first and second seasons respectively, $\mathrm{K}$ is an important major nutrient in cotton production because it affects yield ( Bauer et al., 1998; cassman et al ., 1990; Girma et al., 2007; Mullins et al.,1997) . In the finally studies show that addition of $\mathrm{N}, \mathrm{K} \& \mathrm{~S}$ fertilizers led to increase in yield and its components ( Nascimento et al.,2014; Gwathmey et al., 2012; Ashfaq et al., 2015; Nasseem et al., 1981; Makhdum et al., 2001; sawan et al., 2006 and Sawan 2014.

\section{REFERENCES}

[1] Akhtar, M. Ehsan., Sardar, A., Ashraf, M. M., Akhtarand, M., and Zameer khan.(2003). Effect of potash application on seed cotton yield and yield components of selected cotton varieties-1. Asian J. of plant Sci 2 (8):602-604.

[2] Ashfaq, A., Hussain, N, and Athar, M. ( 2015). Role 
of potassium fertilizers in plant growth, crop yield and quality fiber production of cotton-An overview. Fuuast J. Biol., 5(1):27-35.

[3] Bauer, P. J., May, O. L. and Camberato. J. J. (1998). Planting data and potassium fertility effect on cotton yield and fiber properties. J. prod. Agric. 11:415-420.

[4] Black, A. C., Evans, D. D., White, J. L., Ensminyer, E. L .and Clark, E. F. (1965). Methods of soil analyses. Soc. Agro. Ink. Madison Wiscosin USA.

[5] Cantarutti,R.B;Barros,N.F;Martinez,H.E.PNovals, R.F.Avaliacao(2007) da fertilidade do solo e recomendacao de fertilizants. In NOVAIS, R. L, F; CANTARUTTI, R,B.Vicosa: Sociedade Brasileira de Ciencia do solo, 2007 . p.769-872.

[6] Cassman, K. G., Kerby, T. A., Roberts, B. A., Bryant, D. C. and Higashi, S. L. (1990). Potassium nutrition effects on lint yield and fiber quality of Acala cotton. Crop Sci. 30:672-677.

[7] Girma, K., Teal, R. K., Freeman, K. W., Boman,R. K. and Raun,W. R. (2007). Cotton lint yield and quality as affected by application on $\mathrm{N}, \mathrm{P}$ and $\mathrm{K}$ fertilizers. J. cotton Sci. 11:12-19.

[8] Gormus, O. and El-Sabagh, A. (2016).Effect of nitrogen and sulfur on the quality of the cotton fiber mediterranean conditions.J. of Experimental Bio. And Agric. Sci. .4(6): 662-669.

[9] Gwalhmey, X. H. C. O and Main,C. L. (2012). Sulfur effect on cotton yield components .J. of Better crops. 96(1):27-28.

[10] Jackson, M. L. (1967)." Soil Chemical Analysis " Prentic-Hall,India, New Delhi, pp: 183-203.

[11] Makhdum, M. I., Malik, M. N. A., Chaudhry, F. I. and Din, S. u. (2001). Effect of Gypsum as a Sulphur fertilizer in cotton ( Gossypium hirsutum L.) production. Int. J. of Agric. \& Biol. 3(4): 375-377.

[12] Mengel, K., and Kirkby, E. A. (1987). "Principles Of Plant Nutrition" .International potash Institute.

[13] Mullins, G. L., Burmester, C. H. and Reeves, D. W. (1997). cotton response to in-row subsoiling and potassium fertilizer placement in Alabama. Soil Tillage Res. 40:145-154.

[14] Nascimento, V. D., Mirandam, J. E., Malaquias, J. B., Carvalho, M. D. C. S., Lins, L. C. P. and Paniago, J. (2014). Sulphur sources on the management of Scaptocoris castanea( Hemiptera: Cydnidae ) on cotton . Revista Colombiana de Entomologia 40 (1):15-20.

[15] Nasseem, M. G. and Nasrallah, A. K. (1981). The effect of sulfur on the response of cotton to urea under alkali soil conditions in pot experiments. J. plant and soil .62: 255-263.

[16] Rosolen and Van Mellis, (2010).N utrient deficienciess in corn, sorghums and small grains in Haward B. sprague, 25-58 Mckay, New York.

[17] Sawan, Z. M. (2006). Response of yield components, and fiber properties of Egyption cotton ( Gossypium barbadense L. ) to Nitrogen fertilization and foliarapplied potassium and Mepiquat Chloride. J. of cotton Sci .10 : 224-234.

[18] Sawan, Z. M. (2014). Cottonseed yield and its quality as affected by mineral fertilizers and plant growth retardants .j. Agric. Sci . 5 (3) : 186-209.

[19] Snedecor, G.W. and W.G.Cochran (1967): Statical methods. The Lowa state Univ.press, Ames, Lowa, USA.

[20] Tisdale, S. L., Nelson, W. L. and Beatonm J. D. (1990). "Soil Fertility And Fertilizers" .Macmillan Publishing Company New York.

[21] Twolde, H; K.R Sistani and D.E. Rowe(2005): the effect of N,P and $\mathrm{Mg}$ on cotton plants in different characters. Journal of plant nutraition.28 (4):605-619.

[22] Xiaoli Tian, F. M., Eneji, A. E. and Zhaohu, L. (2016). Cotton yield and potassium use efficiency as affected by potassium fertilizer management with stalks returned to field. Crop. Sci. 56: 740-746. 